\title{
Geological occurrence of the ecce homo hill's cave, chimichagua (cesar), Colombia: an alternative for socio-economic development based on geotourism
}

\begin{abstract}
This work presents the results of the speleological study developed in the Ecce Homo Cerro Cave located in the southwest of the central subregion of the Cesar department, in the Colombian Caribbean region, associated with carbonated rocks of the Aguas Blancas Formation belonging to the Cogollo Group, which have suffered Chemical and mechanical dissolution generating endocárstico and exocárstico environments. In the cavern were found different types of pavillian, paving and zenith speleothems of different sizes in the galleries, being this the tourist attraction of such cavity, such as columns, moonmilk, stalactites, castings, sawtooth, gours and flags. Lithologically, this geological unit is constituted by gray, biomicritic and dismicríticas limestones with high fossiliferous content, intercalations of shales, recrystallized sediments with calcium carbonate, pellets and shells recrystallized with calcium carbonate. The Ecce Homo Cerro Cave can be catalogued as a punctual Geosite with geomorphological interest, taking into account the large number and variety of speleothems presented as well as its excellent state of preservation.
\end{abstract}

Keywords: karstic processes, cavern, limestone, speleothems, ecce homo hill
Volume 2 Issue 5 - 2018

\author{
Ciro Raúl Sánchez-Botello,' Gabriel Jiménez- \\ Velandia,' Carlos Alberto Ríos-Reyes,' Dino \\ Carmelo Manco-Jaraba, ${ }^{2}$ Elías Ernesto Rojas- \\ Martínez, ${ }^{2}$ Oscar Mauricio Castellanos- \\ Alarcón ${ }^{3}$ \\ 'Universidad Industrial de Santander, Bucaramanga, Colombia \\ ${ }^{2}$ Fundación Universitaria del Área Andina,Valledupar, Colombia \\ ${ }^{3}$ Programa de Geología, Universidad de Pamplona, Pamplona, \\ Colombia
}

Correspondence: Carlos Alberto Ríos-Reyes, Universidad Industrial de Santander, Bucaramanga, Colombia, Email carius@uis.edu.co

Received: July 27, 2018 | Published: October 24, 2018

\section{Introduction}

Colombia contains a huge number of resources in underground ecosystems, which are sensitive sites with special features within landscapes referred as karstic environments. Speleogenesis is the formation and development of caves, determining essential features of the hydrogeology of karst and guides its evolution. It often deals with the development of caves through limestone, caused by the presence of water with carbon dioxide $\left(\mathrm{CO}_{2}\right)$ dissolved within it, producing carbonic acid $\left(\mathrm{H}_{2} \mathrm{CO}_{3}\right)$ which permits the dissociation of the calcium carbonate $\left(\mathrm{CaCO}_{3}\right)$ in the limestone. Caves are formed by various geologic processes and can be variable sizes. These may involve a combination of chemical processes, erosion from water, tectonic forces, microorganisms, pressure, and atmospheric influences. Most caves are formed in limestone by dissolution. Currently, three basic genetic settings are broadly recognized for dissolution caves. ${ }^{1}$

a. syngenetic/eogenetic (coastal and oceanic), in young rocks of high matrix porosity and permeability;

b. hypogenic, predominantly confined, where water enters the soluble formation from below, and

c. hypergenic (epigenic), unconfined, where water is recharged from the overlying surface.

Historically, epigenic karst, such as the reported in this study, has received the most attention and is well studied in both regional and theoretical aspects. Epigenic karst systems, which are dominated by shallow groundwater systems receiving recharge from the overlying or immediately adjacent surface, are regularly associated with different types, patterns and segments of flow systems, characterized by distinct hydrokinetic, chemical and thermal conditions; they are predominantly local systems, and/or parts of recharge segments of intermediate and regional systems. ${ }^{2}$ Speleology is an incipient science in Colombia, linked to geology, whose purpose is to study natural cavities. ${ }^{3}$ There are currently 72 studies carried out by different universities, foreign expeditions and private companies. The history of speleology in Colombia dates back to the early 18th century, when Humboldt visited the Iconozo Bridge, the Grotto of Alfonza and the Cave of Los Ladrones, department of Tolima, ${ }^{4}$ but the first explorations of the caves are attributed to Vélez ${ }^{5}$ who performed diverse archaeological explorations in the caves of Moniquirá, department of Boyacá. Numerous works on caverns have been developed since then, ${ }^{6-14}$ Caves are an important georesource, which require integrated and holistic management. Speleosites have a particular use in tourism and recreation, however, it is very important to promote the geoeducation to ensure their protection and preservation. Although the particular case of speleosites is not thoroughly analysed in the geosite literature, many studies regarding cave heritage and management exist. ${ }^{15-18}$ In the municipality of Chimichagua, in the department of Cesar, there is a system of natural caverns associated with carbonated sedimentary rocks of the Aguas Blancas Formation belonging to the Cogollo Group, which have undergone mechanical and chemical weathering generating a karstic relief and environments, consisting of gray limestones with intercalations of shales. The Ecce Homo Hill's Cave is located $5 \mathrm{~km} \mathrm{NE}$ of Chimichagua at the coordinates 1.520.108 North and 1.032.602 East at the main entrance of the cave (Figure 1).The aim of this paper is to report and describe the occurrence of speleothems in the Ecce Homo Hill's Cave (Chimichagua, Colombia), investigating the morphology and mineralogy features of this cave. Special focus is given on its importance as a jewel of the geological heritage. 


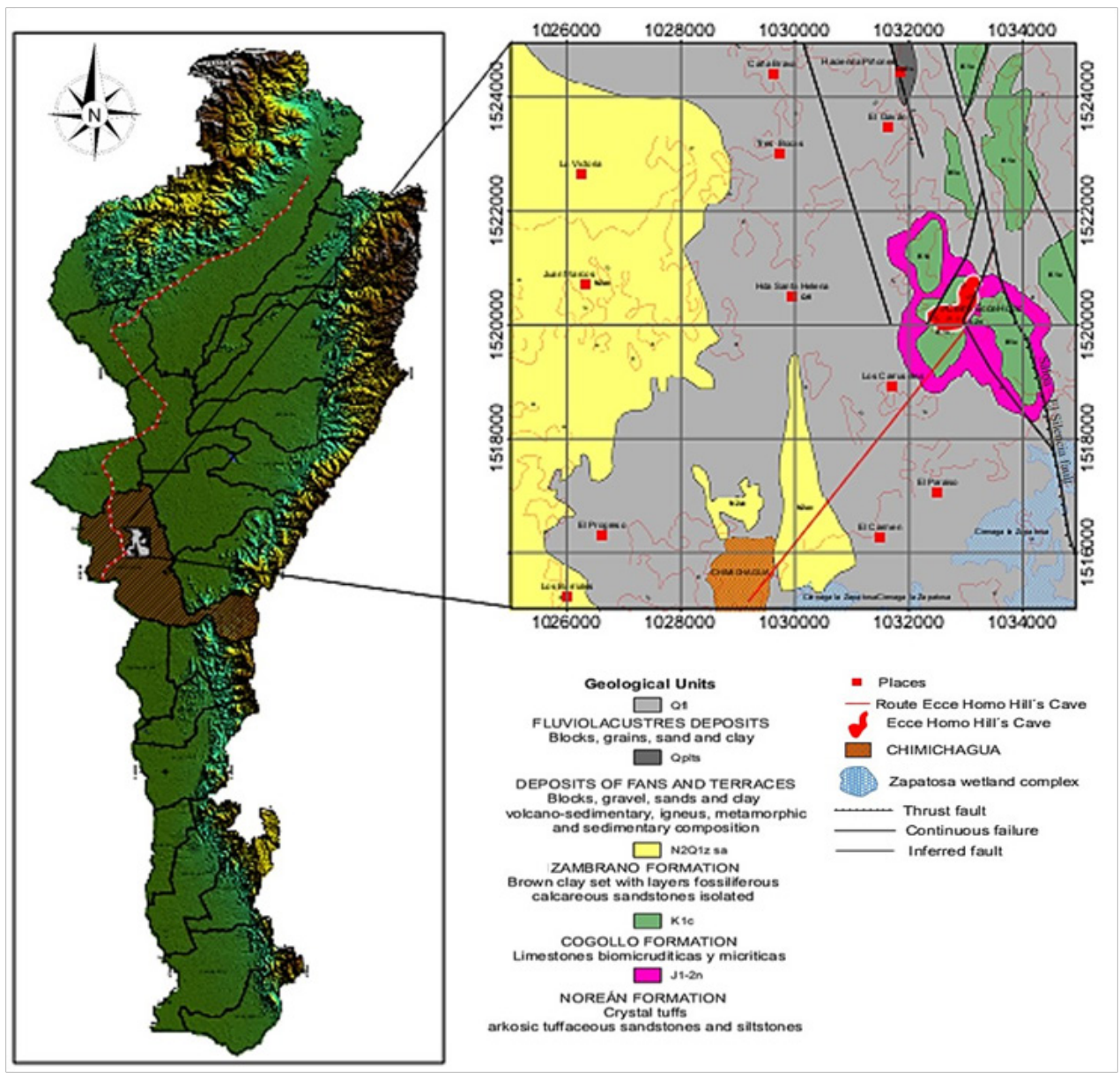

Figure I Location and geological setting of the Ecce Homo Hill's Cave (adapted from geological charts 47 and 55 of the Colombian Geological Service at scale I:100.000).

\section{Geological setting}

In the regional context the area of study, which is in the shores of the extensive Zapatosa Wetland Complex on the Caribbean region of Colombia, is framed in the plain region of Cesar and the lithostratigraphic units outcrops in the municipality of Chimichagua are described below. The term Cogollo Group $(\mathrm{Kc})$ is due to Garner ${ }^{19}$ and Sutton ${ }^{20}$ being introduced by Miller ${ }^{21}$ in the Colombian Perijá Range and the Cesar River valley, subdividing this group into two units namely, Lower Cogollo Member, constituted by massive limestones, sandy limestones and calcareous sandstones with a Barremian-Aptian age and Upper Cogollo Member that consists of thin layered limestones, mudstones and claystones of AptianCenomanian age. ${ }^{22}$ The lower member corresponds to the Lagunitas Formation while the upper member corresponds to the Aguas Blancas Formation. ${ }^{3}$ The Intrusive-Extrusive Complex (JIg-v) is constituted by an intrusive quarzodioritic intrusive rock of acid composition and faneritic texture, composed mainly of quartz, plagioclase and alkaline feldspar (orthoclase), with muscovite as an accessory mineral. In some sectors this rock becomes greenish due to the presence of malachite. This unit is covered in a discordant manner by quaternary sediments. ${ }^{3,23}$ The La Quinta Volcanoclastic Unit (Jqv) crops out parallel to the Curumaní - Pailitas road as a continuous body characterized by an abrupt geomorphology of high slopes. Its age has been defined as Triassic-Jurassic ${ }^{24}$ The volcanoclastic facies indicate a continental-epicontinental sedimentation strongly influenced by an explosive andesitic volcanism of fluctuating intensity, which would reach a paroxysm at the end of the Middle Jurassic period. Its age has been established indirectly on the basis of its stratigraphic relationships as Middle Jurassic-Upper Jurassic and correlates with the Norean Formation. ${ }^{23,25}$ The Arjona Sedimentites (Tpaa) consists of fine-grained sandstones with little cementation, a fine-grained quartz sandstones, silty matrix, yellowish to creamy, slightly cemented, with siliceous stratified bands and sheets of iron minerals and silty matrix sandstones, conglomeratic, with rock fragments ranging from 4 to $20 \mathrm{~cm}$ in diameter, from yellowish to violet, with presence of iron minerals. ${ }^{3,23}$ The term Zambrano layers was introduced by Weiske ${ }^{26}$ to refer to a sequence of calcareous sandstones with fossiliferous banks, outcropping around the municipalities of Carmen de Bolivar and Zambrano, in the department of Bolivar. $\mathrm{Caro}^{27}$ use the original reference by Weiske ${ }^{26}$ but he elevate it to the Zambrano Formation $(\mathrm{Nz})$ range in the piedmont of the Sierra Nevada de Santa Marta, western part of the Department of Cesar, occurring as isolated bodies that have been included in the Arjona Sedimentites described by Tschanz ${ }^{24}$ Recent Deposits correspond to the most recent sediments accumulated by the currents in the flat and semi-plane. Their morphological expression 
is a horizontal (flat) surface where their components are observable in the cuts of rivers and streams, as revealed by a geomorphology of small plains, ripples and hills. ${ }^{3}$ From a tectonic point of view, the main tectonic features are the Chimichagua-Saloa-El Silencio and Soledad faults. ${ }^{28}$ The Chimichagua-Saloa-El Silencio Fault strikes SE-NW and crosses the municipalities of Saloa and Chimichagua. It interrupts its stroke when crashing with the Santa Marta-Bucaramanga Fault in proximity to the municipality of Las Vegas. Its rectilinear stroke puts in contact the Arjona Sedimentites with the igneous intrusive and effusive complex at the locality of El Trébol. It also causes the truncation and elongation of some hills of small elevation where the Arjona Sedimentites crop out, also affecting recent sediments. ${ }^{23}$ The Soledad Fault strikes N-S and crosses the municipality of Soledad detaching from the Chimichagua Fault to the south of Saloa. It affects the recent sediments, the small elevation located to the SE of Saloa where the Arjona Sedimentites crop out, generating its elongation and serving as the western limit of the Jura-Triasic igneous complex. ${ }^{23}$

\section{Field sampling and analytical methods}

A research team developed a fieldwork on the Ecce Homo Hill's Cave, Chimichagua (Colombia), which primarily focused on lithological and morphological features in this cavity. The sampling strategy consisted of taking samples from the outcrops outside the cave and from the walls and speleothems inside the cave. The preparation of the thin section for microscopic analysis was performed on the Sample Preparation Laboratory of the School of Geology, while the mineralogical and petrographic analysis of the sample was performed in a trinocular Nikon (Labophot2-POL) transmitted light microscope to establish the modal percentage of mineral constituents and mineral assemblages, with emphasis on textural relationships between mineral phases, and the photographs were taken using a NIKON AFX-DX microphotographic system of the Research Group in Basic and Applied Geology of the School of Geology. Mineral abbreviations are after Kretz ${ }^{29}$ The mineral phases in a speleothem (to determine the occurrence of calcite or aragonite) were studied by X-ray diffraction using a BRUKER D8 ADVANCE diffractometer operating in Da Vinci geometry with $\mathrm{CuK} \alpha 1$ radiation at $40 \mathrm{kV}$ and $30 \mathrm{~mA}$. Phase identification was performed using the crystallographic database Powder Diffraction File (PDF-2) from the International Centre for Diffraction Data (ICDD). Backscatter electron (BSE) and secondary electron (SE) imaging and EDS analysis of the speleothem were carried out on a FEI QUANTA 650 FEG environmental scanning electron microscope, under the following analytical conditions: magnification $=1000-20000 x, \mathrm{WD}=7.0-11.0 \mathrm{~mm}, \mathrm{HV}=10 \mathrm{kV}$, signal $=\mathrm{SE}$ and $\mathrm{Z}$ CONT, detector $=\mathrm{BSED}$ and $\mathrm{ETD}$.
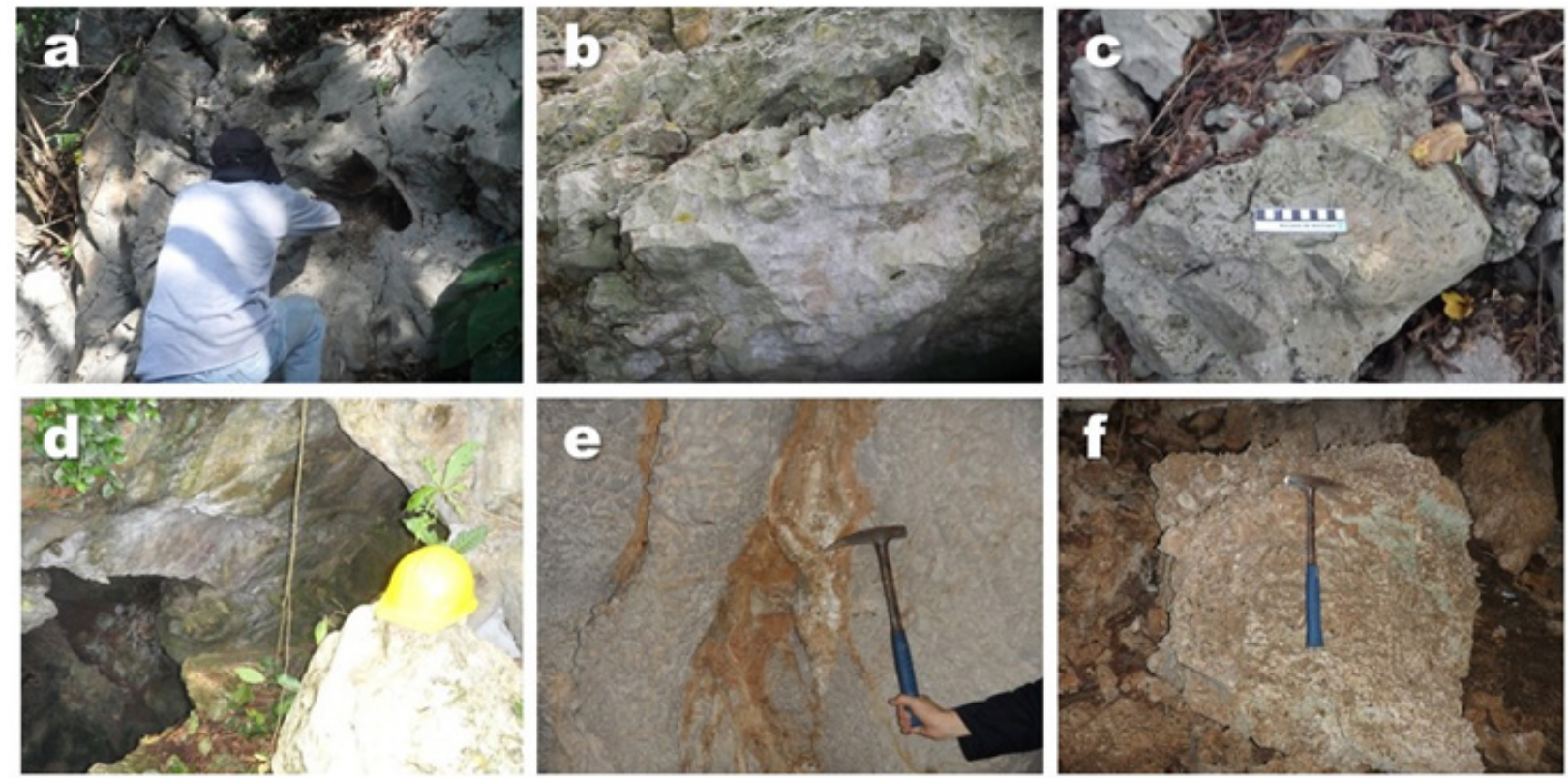

Figure 2 Field photographs of the Ecce Homo Hill lithological features. (a) Calcareous strata of the Aguas Blancas Formation (Cogollo Group) displaying carbonate dissolution; (b) calcareous and fossiliferous strata; (c) fossiliferous limestone with shell fragments; (d) fractured calcareous strata at the entrance of the cave; (e) fracture filled by carbonates inside the cave; (f) fallen calcareous block showing bioturbation inside the cave.

\section{Results}

\section{Field occurrence}

This karstic geoform is characterized by the occurrence of calcareous outcrops of several fossifiliferous content; with compact limestones of $5 \mathrm{~m}$ of thickness and $10 \mathrm{~m}$ of extension in the bottom (45 $\mathrm{m}$ a.s.1.), showing high porosity of sponge like dissolution (holes up to $10 \mathrm{~cm}$ in diameter); more fosiliferous limestones of $5 \mathrm{~m}$ of thickness and $70 \mathrm{~m}$ of extension in the middle parte ( $45 \mathrm{~m}$ a.s.1.) mainly displaying fragments of small shells of several dimensions $(2-6 \mathrm{~cm})$ and aragonite crystallization rims; and in the top (182-187 $\mathrm{m}$ a.s.l.) two caves of 4 and 3 rooms were observed. The cavity is dominated by fractures along the stratification planes. The circulation of water inside the cave is restricted and much of the contribution comes from outside by infiltration along fractures in times of heavy rain. However, at the height of $59 \mathrm{~m}$ a.s.1., in the bottom of the Ecce Homo Hill, the source of La Calera stream washes the Cogollo Formation limestones and then joins to the tributaries of the Zapatosa Wetland Complex. 
On the other hand, around the Ecce Homo Hill wells drilled to 15$26 \mathrm{~m}$ deep are observed, which reveals that within the cave system, there is a potential groundwater storage. Figure 2 illustrates several lithological features of the Ecce Homo Hill.

\section{Characteristics of the cave}

The scientific value of speleothems is determined firstly by their intrinsic and functional values.30 Other important aspects also contributing to their scientific value are considered by several authors. ${ }^{31-40}$ The Ecce Homo Hill's Cave (Figure 3) is currently inactive and on its walls can be evidenced the tracks of streams. On the other hand, new speleothems are forming in very limited areas. It is evidenced that the speleogenesis of this cavity was due to a phreatic level that exerted a fluvial erosion of circulation forced by the hydrostatic pressure through the laminations and joints. As mentioned before two caves of 4 and 3 rooms were observed. The cave 1 is at the height of $187 \mathrm{~m}$ a.s.l. and consists of 4 main rooms; the room 1 has $4.5 \mathrm{~m}$ of width, $7 \mathrm{~m}$ of height and $6 \mathrm{~m}$ of length, where yellowish calcareous rocks were observed leaching of lime compounds which has led to the formation of stalactites with $90 \mathrm{~cm}$ of length and $2 \mathrm{~cm}$ of width; the room 2 was formed in fractured limestone with smaller dimensions compared to the previous room (width $-6 \mathrm{~m}$, height -4 $\mathrm{m}$ and length $-2.5 \mathrm{~m}$ ), on the roof of the room a fracture mineralized with aragonite and curious concentric and needle structures were observed; the rooms 3 and 4 show much smaller dimensions (width $-1.5 \mathrm{~m}$, height $-4 \mathrm{~m}$ and length $-1.5 \mathrm{~m}$ from room 3 , and width -3 $\mathrm{m}$, height $-2.3 \mathrm{~m}$ and length $-4.4 \mathrm{~m}$ for room 4 ). Its compositional variation is unremarkable except in the fractures, since in these rooms they are less prolonged. The cave number 2 is at the height of $182 \mathrm{~m}$ a.s.l. and consists of 2 main rooms; the room 1 has $2 \mathrm{~m}$ of width, 2.5 $\mathrm{m}$ of height and $3 \mathrm{~m}$ of length and was formed in white limestones resulting from the interaction with surface water in times of high rainfall, high fracturing (evidenced in roof collapse in this room) and calcite edges surrounding white limestones; the room 2 was formed in leached and collapsed white limestones with the following dimensions: width $-2 \mathrm{~m}$, height $-3.5 \mathrm{~m}$ and length $-7 \mathrm{~m}$. In general, the cavity shows a single downcomer developed around a fracture perpendicular to the stratification planes of the limestone strata. After access to the cavity, there is a narrow zone with steep slope that climbs as descending. The cavity shows various speleothems (Figure 4), which are described in detail by Lascarro et al. ${ }^{3}$ such as stalactites, coatings and crusts, moonmilks, fallen blocks, coralloids and incipient "rootsicles" (outside vegetation roots reaching the cavity and are coated by calcium carbonate).

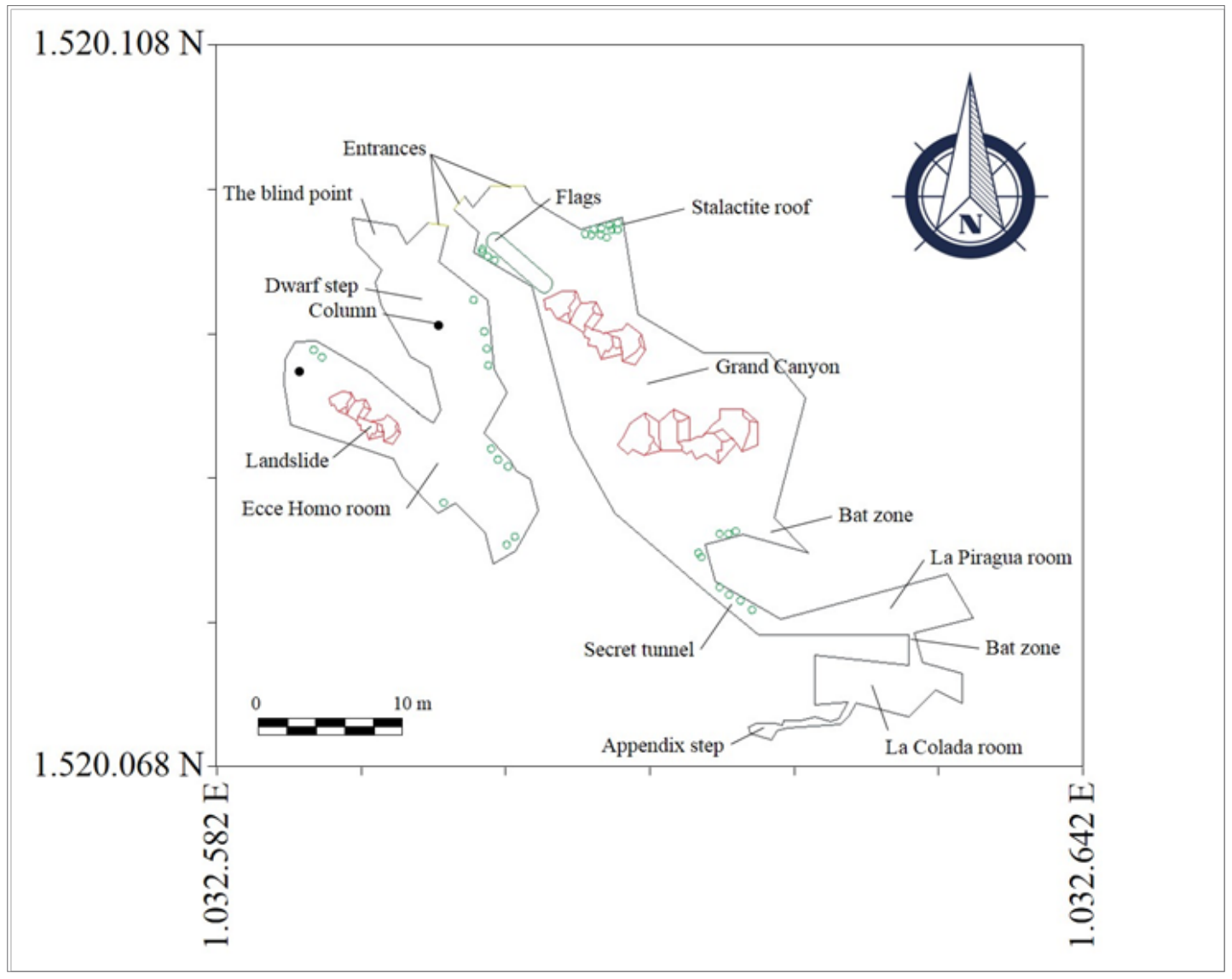

Figure 3 Topographic illustration of the Ecce Homo Hill's Cave (adapted and modified after Lascarro et al., ${ }^{3}$ ). 

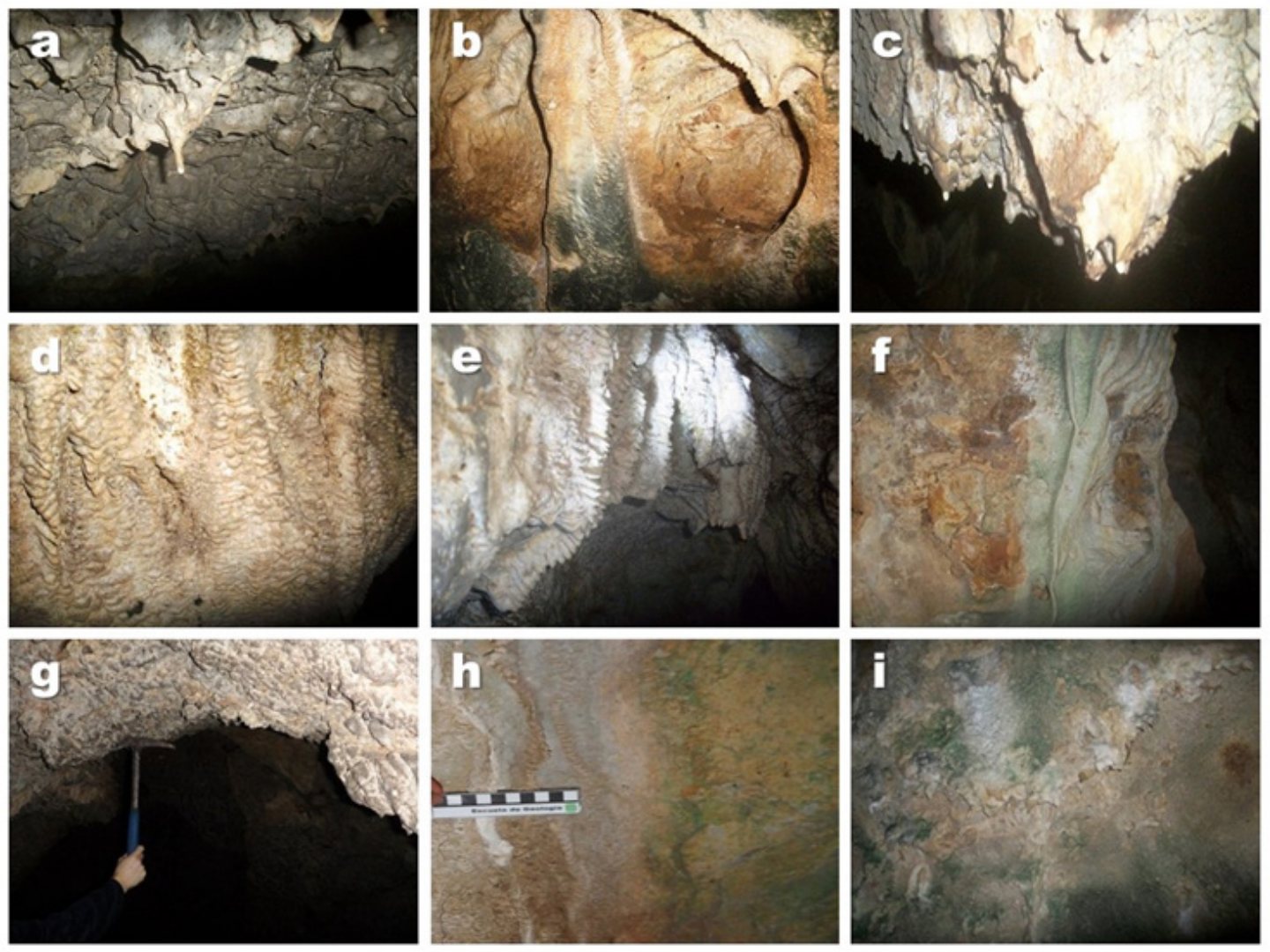

Figure 4 Field photographs of the speleothems at the Ecce Homo Hill's cave. (a) Conical stalactites; (b) column; (c) moonmilk (microcrystalline carbonate aggregates); (d) gours; (e) sawtooth; (f) casting due to surface washing; (g) nodular or globular speleothem (coralloids); (h) rootsicles (at the base of the photo) or outside plant roots; (i) flag.

\section{Petrographic analyses}

Macroscopic description. The limestones cropping out in the study area correspond to a massive gray rock of the Aguas Blancas Formation belonging to the Cogollo Group, mudsupported type with high fossiliferous content, with pellets and veinlets recrystallized with calcium carbonate. According to Folk ${ }^{41}$ they can be texturally classified as calcarenite. Compositionally, they correspond to micrites with fossils and intraclasts according to Folk ${ }^{42}$ and wackestones according to Dunham ${ }^{43}$ Macroscopically, it was possible to establish that these rocks have a sandy matrix of fine to medium size, effervescence with HCL, compact, with medium density, gray coloration and mottled with iron oxides and organic matter, with straight bands cemented with carbonate and iron oxides that are observed in their interior. There are also clasts included in the sandy matrix, which can correspond to oxidized pyrite with sphalerite and which, in turn, has reaction rims with iron oxides. These rocks can be classified as calcoarenites with clasts and organic matter inside. General macroscopic characteristics of the rocks cropping out in the Ecce Homo Hill where a cavern was excavated in limestones of the Aguas Blancas Formation (Cogollo Group) are illustrated in Figure 5 \& Figure 6. According to Lascarro et al. ${ }^{3}$ these rocks were deposited in a shallow marine platform environment, due to the presence of foraminifera that they would indicate a depth no greater than two hundred meters. On the other hand, these authors consider that veins filled with recrystallized limestone show that the basin was very likely subjected to tectonic stresses, which generated a rise and variations in sea level, passing into a coastal environment of a restricted basin, and for these reasons the presence of iron oxides.

Microscopic description The analyzed rocks corresponds to a massive, brown calcareous organic matter-rich mud. It presents in general fossils $(>10 \%)$ and some particles of quartz $(<10 \%)$. There are some very thin veins composed of carbonates that cut the rock, in general the muddy matrix is brown due to the content of organic matter in the sample. Figure 7 illustrates the main textural and microstructural features of the rocks that constitutes the speleothems at the Ecce Homo Hill's Cave: (a)-(b) Packstone bioclastic limestone with fragments of shells, echinoderms and algal remains (oncoliths). Presents recrystallized veins with calcite. (c)-(d) Crystalline limestone with acicular bands of oxides and striations in the crystals, product of the precipitation of calcite. (e)-(f) Crystalline limestone with fragments of esparite (calcite) filling fractures, with presence of oxidation in the edges and deformation grooves. (g)-(h) Bioclastic wackstone type limestone with calcite recrystallized pellets and stalks, presence of planktonic foraminifera, algal fragments and dislocated shells of bivalves. (i)-(j) Crystalline limestone with concentric hexagonal zonation of oxides inside the calcite crystals. (k)-(l)Crystalline limestone with presence of solution of calcite on the edges of the glass. 

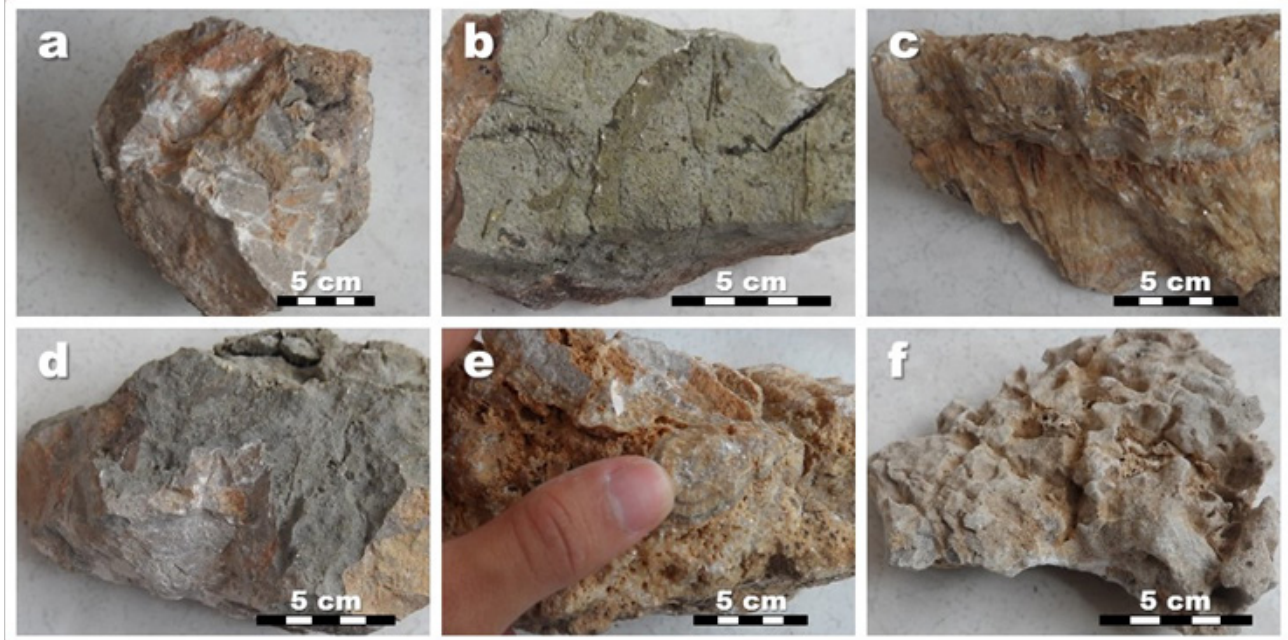

Figure 5 Photographs of hand specimens of rocks cropping out at the Ecce Homo Hill. (a) Mudstone with veinlets of calcium carbonate; (b) mudstone with shell fragments up to $2 \mathrm{~mm}$; (c) acicular and banded carbonates; (d) massive mudstone; (e) concentric structure of calcium carbonate; (f) mudstone showing dissolution.
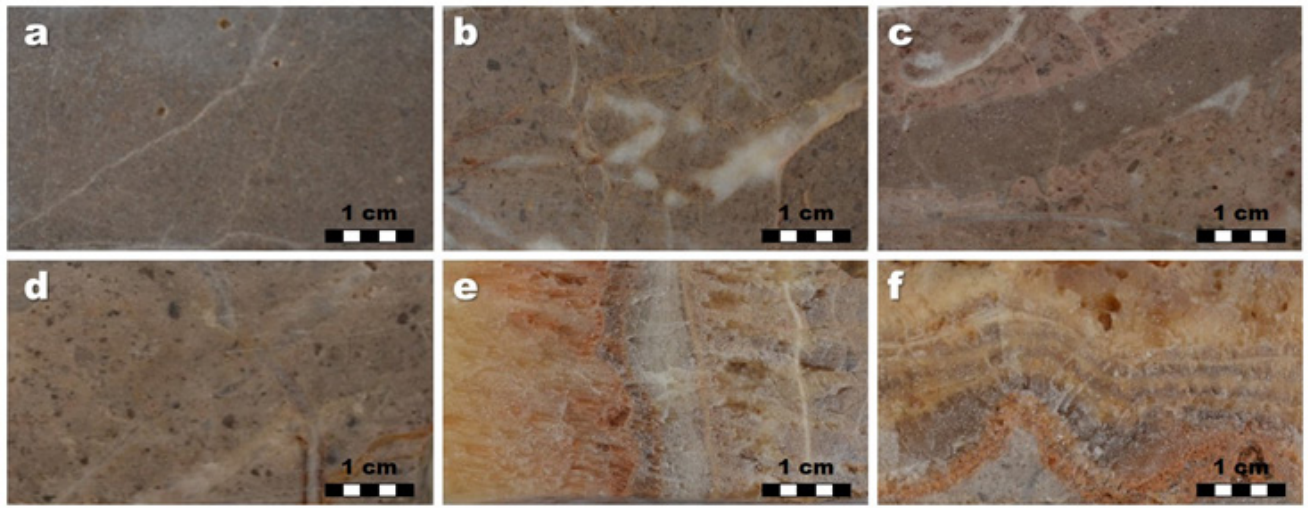

Figure 6 Photographs of polished specimens of rocks: (a) mudsoported limestone (mudstone) with low fossiliferous content; (b) limestone of mudstone type with vein of recristallized $\mathrm{CaCO} 3$; (c) mudsoported limestone with pellets and vein of recristallized $\mathrm{CaCO}_{3}$; (d) mudstone with pellets and recristallized $\mathrm{CaCO}$ shells; (e) calcite developing banded (in the central part) and acicular (in the ends) aggregates; (f) calcite with banded and concentric structure (in the central part) with oxides.
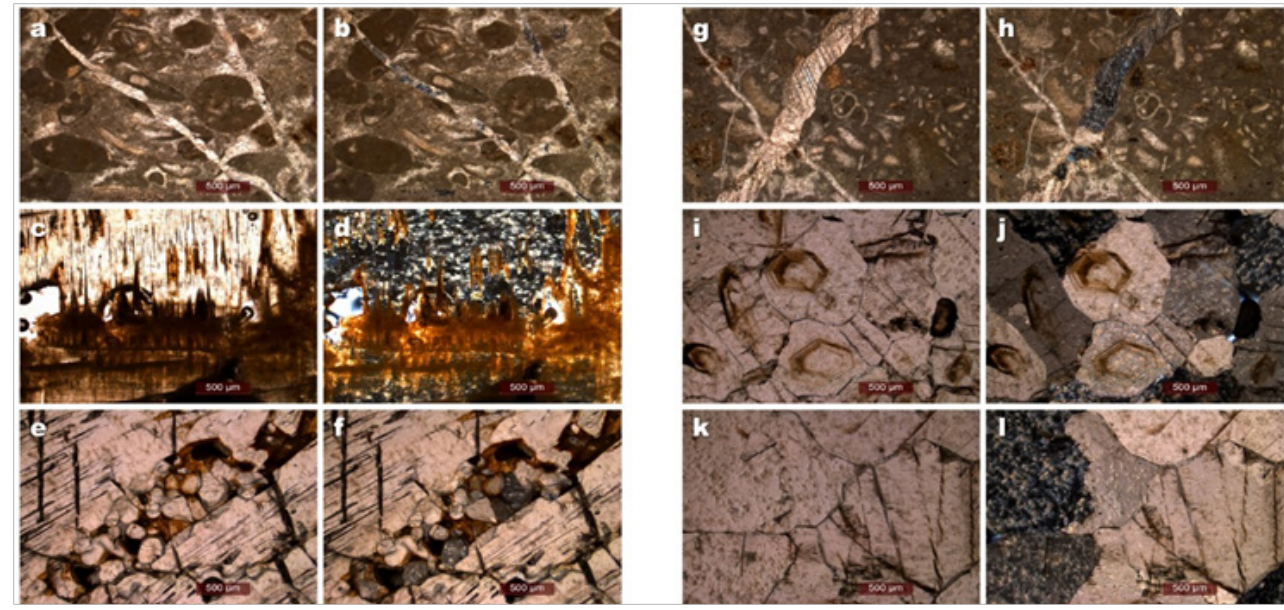

Figure 7 Main textural and microstructural features of the rocks that constitutes the speleothems at the Ecce Homo Hill's Cave. Each pair of photomicrographs (left) PPL and (right) XPL; Magnification 4x.

Citation: Sánchez-Botello CR, Jiménez-Velandia G, Ríos-Reyes CA, et al. Geological occurrence of the ecce homo hill's cave, chimichagua (cesar), Colombia: an alternative for socio-economic development based on geotourism. Int J Hydro. 20I8;2(5):618-628. DOI: 10.15406/ijh.2018.02.00I34 
The speleothem was identified as calcite by X-ray diffraction, both in the analyzed sample. In contrast, aragonite was not detected. Previous studies do not reveal the occurrence of aragonite. Signals other than calcite were not identified in any of the carbonate samples (Figure 8). Figure 9 shows the backscattered scanning electron (BSE) image and the corresponding EDS spectrum of a typical calcite of a speleothem. SEM images and EDS analyses of speleothems are illustrated in Figure 9. Microstructural observations were done on a sample taken from the cave wall host rock (Figure 10).

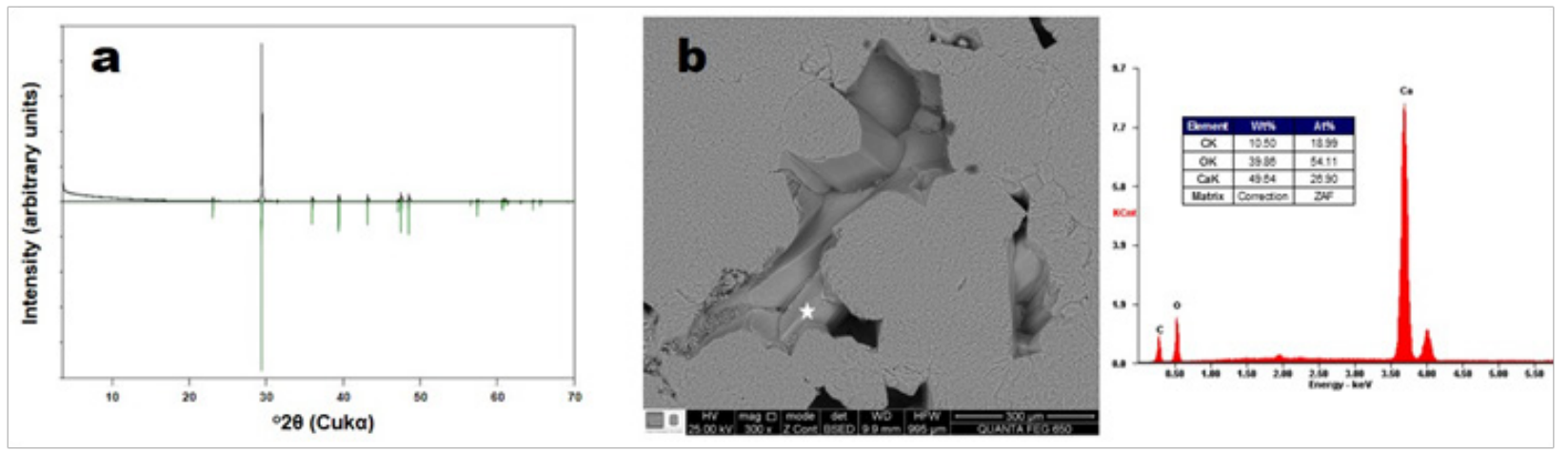

Figure 8 (a) XRD pattern of a speleothem composed by calcite. (b) SEM image and EDS analysis of a speleothem.
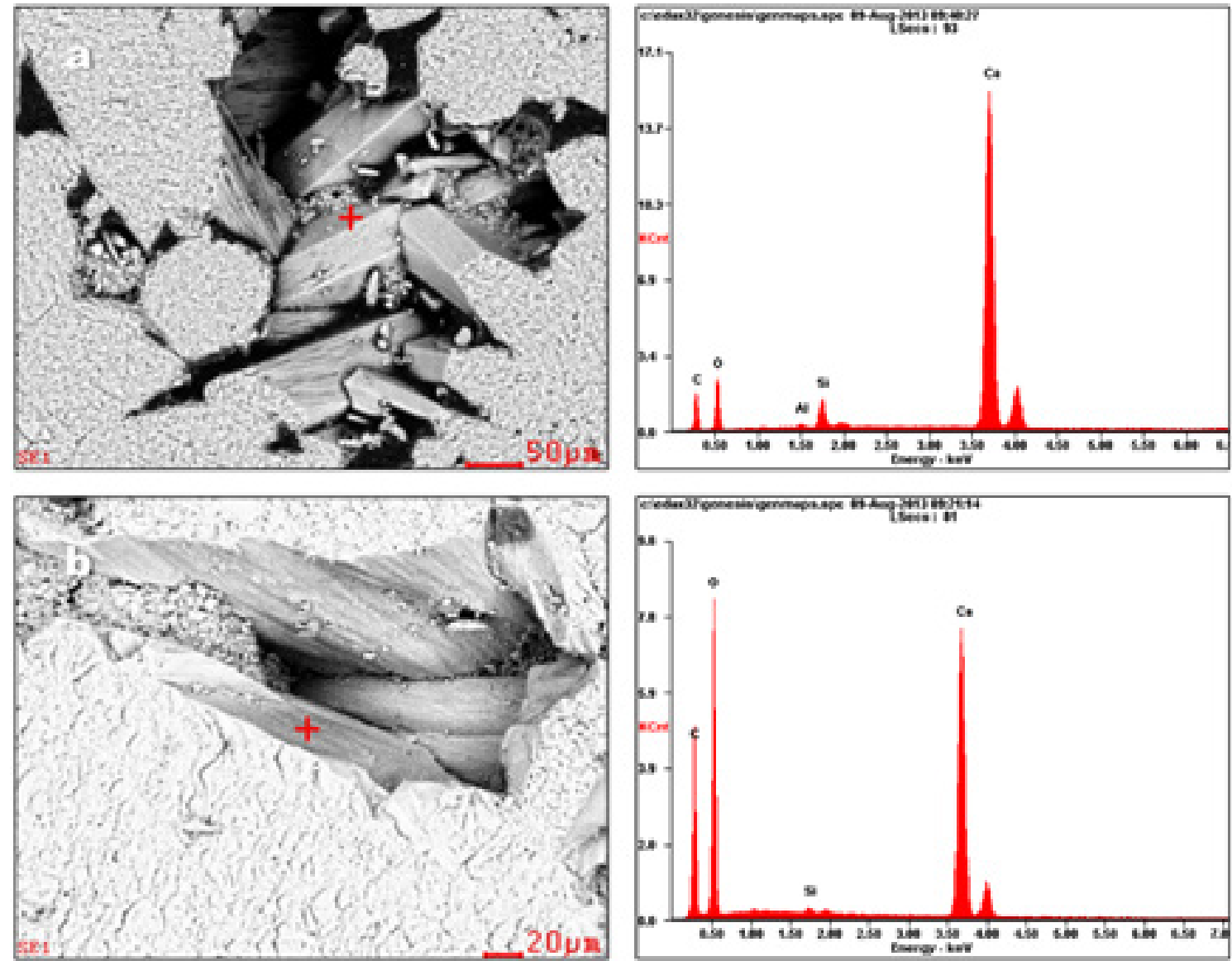

Figure 9 SEM images and EDS analyses of (a) banded and acicular speleothem and (b) concentric speleothem. 

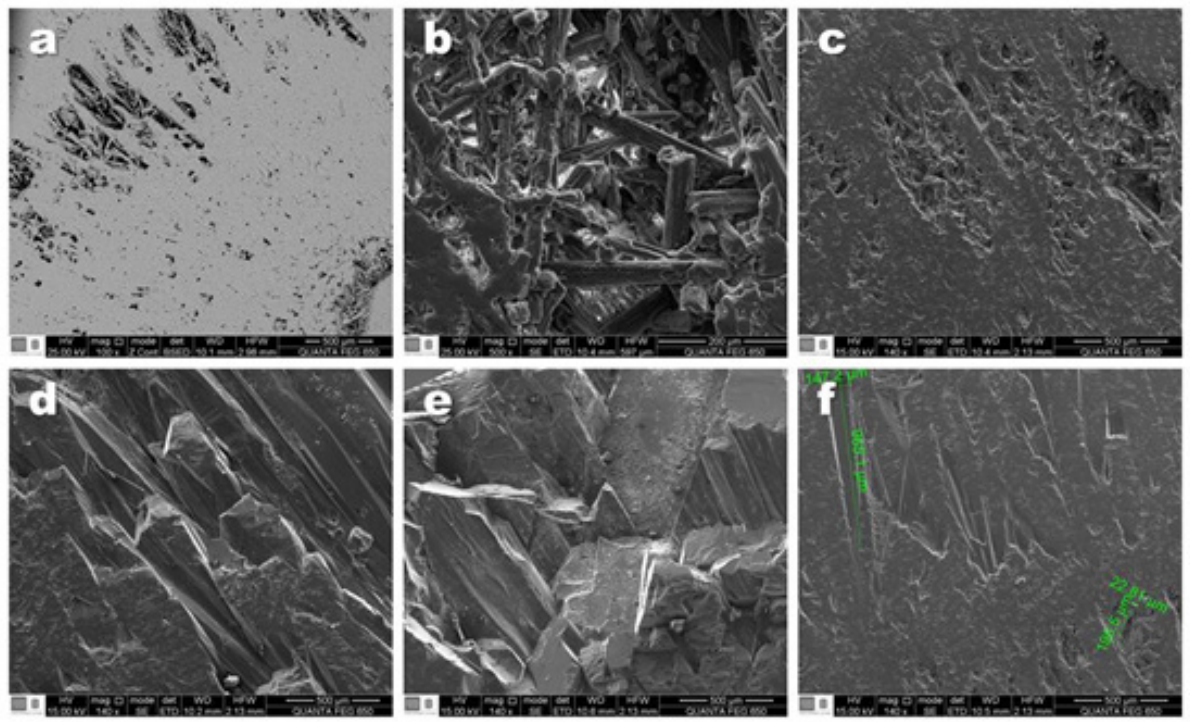

Figure 10 SEM images of the speleothems.

\section{Morphogenesis}

Currently the system of caverns of the Ecce Homo Hill's Cave shows an advanced state of fracturing, allowing the entry of surface water acts forming speleothems such as stalactites, castings and crusts, moonmilks, fallen blocks, coralloids, among others. The clean substrate of the cave system indicates that there is little hydric movement and feeds in the formation of speleothems are due to infiltration of runoff modeling the upper and outer part of the system as evidenced by the solutions of the karst system. The formation of coralloids points to the existence of lakes, since one of their origins is linked to underwater media. However, the origin of these coralloids can be associated to a subaerial media involving the presence of thin films of water infiltrated along fractures lining the walls of the cave system. The surface area where the study of the Ecce Homo Hill's Cave is performed was at the same level at first, which means that it was a flat surface. Rainwater dissolves a portion of carbon dioxide as

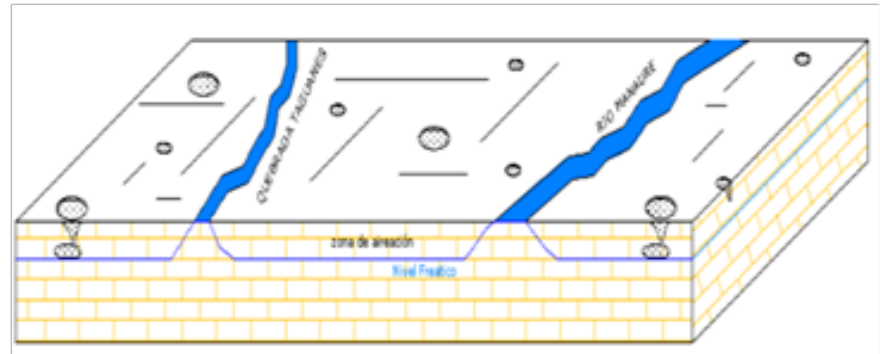

Figure I I Genesis of the Ecce Homo Hill's Cave. ${ }^{48}$

\section{Karst geotourism}

Geotourism deals with geology, geomorphology, natural outlooks and the forms of earth surface, layers with fossil, rocks and minerals with emphasis on the creating processes. ${ }^{44}$ It has rapidly developed in the last two decades and is one among many types of ecotourism or nature tourism. Cave tourism within geotourism has gained popularity it passes through the atmosphere forming carbonic acid. This acid, when contacted with limestone, forms calcium bicarbonate (soluble substance and easy to transport by water), allowing a chemical and mechanical erosion, and widening the cracks, micro faults, diaclases among others by the continuous dissolution during transit of the water and carrying with it the dissolved material. This fluid at a given moment found an intercalation of shales, which prevented flow in the vertical direction by forcing it horizontally and forming a water table, creating the traces of currents that are evident in its walls and galleries today. The chemical process that produces the dissolution of the calcium carbonate, can be reversible because as the carbonatedissolved water is transported undergoing temperature, pressure and evaporation changes, and can cause precipitation of calcium carbonate. This precipitation is responsible for the formation of different speleothems, which according to their location and geoform has their classification (Figure 11).

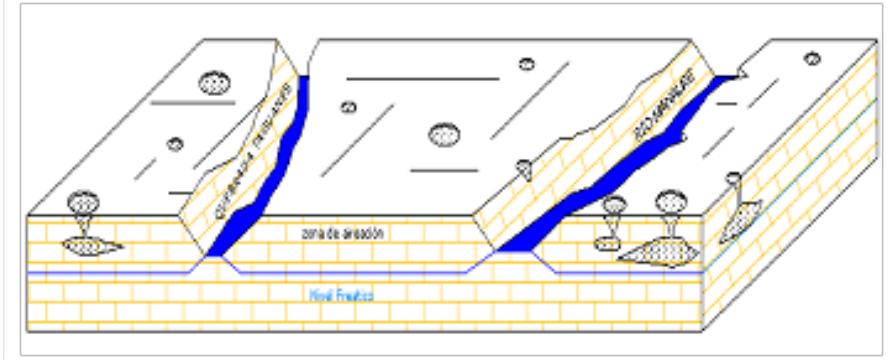

around the world. A study of geotourism around this region should include cave tourists' characteristics, segmenting them according to motivation factors, and finally identifying who they are. Although the Ecce Homo Hill's Cave does not appear in the inventory of Geosites, it should be catalogued as a punctual Geosite with geomorphological interest. The main attraction of this small cave is the large number and variety of speleothems presented as well as its excellent state of 
preservation. Access to the cave can only be done through guided visits, altruistically, for individuals associated with the Zapatosa Wetland Complex, which has ecological resources, beautiful coastal beaches and islands, accompanied by activities and water sports that can be practiced in their waters and religious and cultural events, which represent the main potential of the municipality of Chimichagua as a tourist destination to promote economic growth. Until recently the number of visitors has been very low, however, this number has increased considerably, especially visits with research interest groups. As in many other places, the visit to the cave includes explanations of their finding and the observation of the most striking speleothems but does not provide geological data on it. The physical fitness of the cave made for visits is discreet and includes soft lighting and spot that allows to observe the most striking speleothems. There are not temperature and humidity sensors, and therefore there is no monitoring of the variations of these parameters and evaluating the potential impact that a high number of visitors can be in a cave in such small dimensions. On the outside, the infrastructure is scarce, and that does not include access road, parking, next source and recreational area.

The cave described could be classified as a Geosite belonging to the Early Cretaceous Geological Context. This location means that in the vicinity could find other Geosites, which have not yet been rated by a route that highlights not only the historical values but also the geological ones. In our opinion, the presence of a world-class geological heritage in the Zapatosa Wetland Complex environment should be used by geotourism as a socio-economic strategy in order to establish sustainable alternatives in this region. Underground geotourism has different forms, some of which are long established and are well able to attract tourists and produce income and investment. The speleotourism is an activity that is located as part of alternative touris. ${ }^{45}$ The damages to these underground ecosystems are related to the extermination of bats, aquifer contamination and/or the obstruction of their orifices with fillers of garbage or other wastes. However, underground ecosystems are very interesting scenarios because inside them it is possible to observe impressive speleothems. Caves represent natural laboratories that carry out important ecological functions such as: they are bodies of reserve and water drainages, refuge of endemic species, regulators of the climate, records of the climate for thousands of years, place of abundant fossils, minerals and also, where you can find evidence of ancient cultures. To recognize more the important function of the Ecce Homo Hill's Cave could be the base to promote their valuation and greater regulation in our country and for the department of Cesar and that are not regulated in the use and forms of access of their interiors. From a socio-environmental point of view, it does not really have an adequate infrastructure, there is no planning on the part of the tour operators, with the absence of trained native guides and quality services, there is a lack of basic services, signaling, security, first aid, among other aspects, for the development of geotourism. On the other hand, there is no social inclusion or geoeducation. The Ecce Homo Hill's Cave has been altered from their natural state, with the progressive deterioration of the internal galleries due to graffiti and scratches on the crust of the internal walls, as well as the looting of stalactites and stalagmites, which causes irreversible damage to their ecological and scenic conditions, as a consequence of the lack of regulation policies. Informal tourism has not followed the basic principles that, together with reason and the desire to act ethically, allow sustainable development, which is reflected in the indiscriminate disposal of garbage inside and outside the caverns, such as cigarette packs, beverage containers, photographic film wraps, remains of provisions, among others, as well as the making of campfires scattered around the caverns. The latter is an aspect to consider as the surrounding vegetation can be very vulnerable to forest fires. These considerations are of great importance, since in addition to representing an attraction for nature tourism, the caverns represent ecosystems that are part of the geological heritage of Santander, have a large amount of underground aquifers, serve as habitat for species, and maintain important ecological functions and environmental services.

Local communities must ensure greater social and economic benefits of tourism. Tourism has proven to be one of the most effective means of boosting job creation and economic development in local communities. However, it is necessary to consider aspects of tourism ethics and responsible tourism. Local communities should be organized legally with an Assembly, as the highest authority, composed of all of its members. Within the organization should be a committee of tourism, which is composed of a president, a secretary and a treasurer, with management capacity before various instances, with the participation of native guides as volunteers in the provision of speleotourism services. On the other hand, it is important to link the students of schools of the region as volunteers in the maintenance of tourist areas, such as trails, roads, interior and exterior of caverns, parks, etc. However, it is important for the development of the ecotourism activity the governmental support in the tasks of maintenance and adaptation of infrastructure. In our country, although there are successful tourism projects, the great majority are far from being a real option for the development and improvement of living conditions. This has generated in the local communities attitudes of apathy, lack of sense of territorial relevance, commitment and credibility towards the governmental entities. Local communities feel that private interest is often privileged, rather than collective, which generates distrust and requires greater efforts of supervision and vigilance among them. It is important to have the participation of experts in speleology, who must document the state of the caverns, the cataloging of speleothems, the layout of suggested routes for the transit of visitors and identification of species of fauna and flora existing inside and of the vegetation of its surroundings. It is advisable to avoid fixed lighting installations and the use of guardrails inside the caverns, as this would generate a strong environmental impact. Therefore, it is necessary that both guides and visitors use special lamps during the tour. In order to contribute to the tourist infrastructure, ecological baths and cabins could be built to accommodate visitors, both located in the vicinity of the caverns, and to open a reception desk for visitors, with an ecological bath, helmets with headlights, hand lamps for guides and visitors, battery chargers and first aid kits. The training of native guides is fundamental to educate them for properly guiding visitors. The installation of location, descriptive and interpretive signage is of great importance as an educational tool to guide geotourism. It is also important to link the department of Cesar's private sector, government institutions and local communities.

Government institutions can grant resources, although in many cases it occurs without integrated or participatory planning, without considering the studies of environmental impact or social viability of the project. The local communities do not have regulatory policies regarding the care and respect that must be had towards the caverns and the infrastructure that has been generated for the development of geotourism. Therefore, if the natural and cultural heritage of the caves is not guarded by the inhabitants of the region, these subterranean 
ecosystems are very vulnerable, as a consequence of the lack of territorial relevance and regulatory policies. However, if there are no monitoring mechanisms, the regulations established by the local communities will not be effective. ${ }^{46}$ The activities developed in the Ecce Homo Hill Cave are focused on ecotourism walks by the people surrounding the study area. These visits are often made for the dates of the municipality's patron festivities, by a guide to visualize the diversity and contrast of the flora and fauna of this underground ecosystem with its surroundings. Previously in the cavern cults or rites associated with the religious festivities of the municipality were developed; which consisted of transferring the image of the patron saint of the town (Santo Ecce Homo) together with the parishioners to the Ecce Homo Hill cavern and then transported back to the village church. For the year 2014, the Zuluaga family applied for the title before the National Mining Agency for the extraction of the geological potential of the Ecce Homo Hill but it was denied because the area of interest is very close to the Zapatosa Wetland Complex. ${ }^{47}$

The role played by these cavities in the forests is fundamental for the preservation and development of these, due to the role played by various endemic species such as bats, thousand feet, spiders, cockroaches, among others. Unfortunately the owners of these properties allow access to people who do not know the importance of these ecosystems, developing activities that influence the detriment of the heritage that enclose these karstic environments, since many of these ecosystems are being used for rites, excursions, extraction of its geological potential, among others, this due to the industrial demand (construction) that today confronts the department of Cesar. It should be noted that there was evidence of rubbish and graffiti at the entrance of the cavern and in the main gallery. From the above, it is concluded that the importance of the conservation and preservation that these karstic ecosystems deserve in the department of Cesar has not yet been given, due to the lack of knowledge of the influential people in this area. The dangers evidenced in the study are focused on the preservation of the endemic species of this cavity, this due to the inadequate acts generated by the community in general.

\section{Conclusions}

The Ecce Homo Hill's Cave is developed entirely within the associated with carbonated rocks of the Aguas Blancas Formation belonging to the Cogollo Group. These rocks probably deposited in a shallow marine platform environment, due to the presence of foraminifera that they would indicate a depth no greater than two hundred meters. It contains different types of pavillian, paving and zenith speleothems of different sizes in the galleries, being this the tourist attraction of such cavity, such as columns, moonmilk, stalactites, castings, sawtooth, gours and flags. In this cave inhabit colonies of bats, mice, spiders, cockroaches, among others, which could be endemic species of the area and nourish the biodiversity of Colombia. The genesis of these cave is related to leaks of water loaded with $\mathrm{CO}_{2}$. This mixture forms carbonic acid, which reacts with $\mathrm{CaCO}_{3}$, the main chemical constituent of limestones. This process was expanding the fissures present in the rocky massif to give it the shape it has in the present. Muddy sediments are found on the floor of the cave, which are waterproof, preventing the continuation of decrease in $\mathrm{H}_{2} \mathrm{CO}_{3}$ filtering through cracks. Upon encountering this impermeable rock, the $\mathrm{H}_{2} \mathrm{CO}_{3}$ begins to move horizontally, forming the current galleries and steps of the Ecce Homo Hill's Cave. It can be catalogued as a punctual Geosite with geomorphological interest, taking into account the large number and variety of speleothems presented as well as its excellent state of preservation. ${ }^{49}$

\section{Acknowledgements}

We thank the Universidad Industrial de Santander for allowing us the use of the research facilities. We thank Luis Garrido for assistance in thin section preparation. Thanks to professionals of the PTG labs in collecting XRD and SEM data. Special thanks to the Group Geological Engineering Research of the Fundación Universitaria del Área Andina, for provides us the topography of the Ecce Homo Hill's Cave, and the report made after the discovery of the same. Special thanks to the Councilor of the municipality of Saith Sampayo, the professor of tourism, Yeiro Perez Moreno, to Ciro Sánchez, Dámaris Botello, Jessica Rodríguez, Jorge Sánchez, Jaime Guerrero and Paola Fernandez for participating in the collection of samples, adding photographs and provide support as guides. The authors also acknowledge to the anonymous referees for their critical and insightful reading of the manuscript and are most grateful to the above-named people and institutions for support.

\section{Conflict of interest}

The authors declare that there is no conflict of interest.

\section{References}

1. Ford DC, Williams PW. Karst Hydrogeology and Geomorphology. Wiley, Chichester. 2007.

2. Klimchouk A. Morphogenesis of hypogenic caves. Geomorphology. 2009;106:100-117.

3. Lascarro F, Cormane F, Rojas E. Estudio geoespeleológico de la Caverna del Cerro Ecce Homo en el municipio de Chimichagua, Cesar. Revista Ingeniería, Investigación y Desarrollo. 2015;15(2):6-14

4. Humboldt A. Sitios de las cordilleras y monumentos de los pueblos indígenas de América. Madrid.1810;1-242.

5. Vélez M. El Dorado: noticias sobre las antigüedades de la Nueva Granada por D. Manuel Vélez, Papel Periódico Ilustrado, Bogotá. 1984;4(76):54-58.

6. Le Doussal E. Excursión al Paramo de Santurbán. Universidad Católica, Pamplona. 1917;(889):4-10.

7. Bürgl H. Las cuevas del Compadre de Tota. Boletín Geológico, Servicio Geológico Nacional, Bogotá D.E. 1958;(12):4-10.

8. Correal G, Van der Hammen T. Resumen de los resultados de una prospección arqueológica en la Cueva de Los Guacharos, departamento del Huila. Revista de Antropología, Universidad de Los Andes, Bogotá. 1988;4(2):255-271.

9. Acosta C, Cabrera W, Tihay N. Expedition Francaise de Speleologie. Instituto Geográfico Agustín Codazzi. 1997;120.

10. Acero D, Velandia F, Ramirez J. Geoespeleologia en el NW de la provincia Guanentina, departamento de Santander. XI Congreso Colombiano de Geología, Bucaramanga. 2007.

11. Muñoz-Saba Y, Gonzáles I, Calvo N. Cavernas de Santander Colombia. Revista Geología Colombiana de la Universidad Nacional de Colombia Bogotá D.C. 2013;1-325.

12. Hoyos M, Muñoz-Saba Y. Cavernas en Santander: fauna y aprovechamiento estratégico. XI Congreso Colombiano de Geología, Bucaramanga. 2007.

13. Manco DC. Análisis de los impactos ambientales causados por el mal uso en la Caverna Sabana de León y Cueva Coco Loco en el municipio de Manaure, Serranía de Perijá, departamento del Cesar. Tesis de Especialización en Ingeniería Ambiental. Universidad Industrial de Santander. 2014;68. 
14. Manco DC. Descripción de los impactos ambientales causados por el mal uso en la Caverna Sabana de León y Cueva Coco Loco en el municipio de Manaure, Serranía de Perijá. Departamento del Cesar (Colombia). XVI Congreso Colombiano de Geología y III Simposio de Exploradores. Santa Marta, Colombia. 2017.

15. Smith MJ, Burns GJ. Australia's crystalline heritage: issues in cave management at Jenolan Caves. Helictite. 2011;40(2):27-34.

16. Jiménez-Sánchez M, Domínguez-Cuesta MJ, Aranburu A, et al Quantitative indexes based on geomorphologic features: A tool for evaluating human impact on natural and cultural heritage in caves. Journal of Cultural Heritage. 2011;12(3):270-278.

17. Cigna A, Forti P. Caves: The Most Important Geotouristic Feature in the World, Campinas, SeTur/SBE. Tourism and Karst Areas. 2013;6(1):9-26.

18. Roberts N. The Cultural and Natural Heritage of Caves in the Lao PDR: Prospects and Challenges Related to Their Use, Management and Conservation. The Journal of Lao Studies, Special Issue. 2015;113-139.

19. Garner AH. Suggested nomenclature and correlation of geological formations in Venezuela. Amer Inst Min Metall Eng. 1926;677-684.

20. Sutton FA. Geology of Maracaibo basin, Venezuela. Am. Assoc. Petrol Geol Bull. 1946;30(10):1621-1741.

21. Miller J. Directrices Tectónicas en La Sierra de Perijá y Partes Adyacentes de Venezuela y Colombia. Bol Geol Minis Min Hidroc Publ Esp. 1960;2:685-718.

22. Goveas C, Dueñas E. Informe geológico de la cuenca del río Cesar ECOPETROL. 1975.

23. Ortega C, Manco D, Rojas E. Exploración geoquímica de los recursos auríferos en el sector de Saloa (Chimichagua), Cesar. Revista Ingenium. 2014;8(20):27-38.

24. Tschanz CM, Jimeno A, Vesga C. Geology of the Sierra Nevada de Santa Marta área (Colombia). Instituto de Investigaciones e Información Geocientífica, Minero - Ambiental y Nuclear. República de Colombia. $1969 ; 288$.

25. Clavijo J, Barbosa G, Bernal L. Mapa Geológico de la Plancha 75, Aguachica. INGEOMINAS, Bucaramanga. 1997.

26. Weiske F. Estudio sobre las condiciones geológicas de la Hoya del Río Magdalena. Comp Est Geol Ofic Colombia. 1938;4(15):124

27. Caro D. A reply to: On planktonic foraminiferal zonation in the Tertiary of Colombia. En: Estados Unidos Micropaleontology.1971;17(3):365-368.

28. INGEOMINAS. Mapa Geológico sector de Chimichagua. 2006.

29. Kretz R. Symbols for rock-forming minerals. American Mineralogist $1983 ; 68: 277-279$.

30. Cocean G. Preliminary considerations upon the main types of speleosites in the Apuseni Mountains (Romania). Romanian Review of Regional Studies. 2015;11(2):107-114.

31. Piccini L, Sauro U, De Waele J, et al. The Italian Register of Natura Hypoggean Geosites: a Preliminary Report. Il Quaternario Italian Journal of Quaternary Sciences. 2005;18(1):155-162.

32. Muños P, Alonso A, Sánchez S, et al. Los estudios científicos como herramienta para la conservación y gestión del Monumento Natural Cueva de Castañar (Extremadura). Universidad de Oviedo. 2006;175-185.
33. Sanjurjo J, Vidal J, Pallí L, et al. Espeleotemas de ópalo y pseudocarst granítico. Revista C\&G. 2007;21(1-2):124-134.

34. Martín A, Martín R, Alonso A. Geoquímica isotópica $\left(\delta^{18} \mathrm{O}\right.$ y $\left.\delta^{13} \mathrm{C}\right)$ de los espeleotemas de aragonito, calcita y dolomita de la Cueva de Castañar de Ibor (Cáceres). Geo-Temas. 2008;1566-1568.

35. Wong CI, Banner JL, Musgrove ML. Seasonal dripwater $\mathrm{Mg} / \mathrm{Ca}$ and $\mathrm{Sr} /$ $\mathrm{Ca}$ variations driven by cave ventilation: Implications for and modeling of speleothem paleoclimate records. Geochimica et Cosmochimica Acta. 2011;75(12):3514-3529.

36. Gillieson DS. Management of Caves. In: Van Beynen PE, Editors. Karst and Cave Management, Springer, New York. 2011;141-158.

37. Galán C, Vera C. Espeleotemas de cuarzo silicatos de hierro y aluminio, en una cueva hidrológicamente activa en arenisca de la formación jaizkibel (gipuzkoa, país vasco). Descripción general de la cavidad y caracterización química por espectroscopía raman y difracción de rayos $X(d r x)$. 2010;1-12.

38. Galán C, Nieto M, Vera C. Discovery of speleothems and bedded deposits of Jacobsite in Aixa Cave. 2011

39. Briestenský M, Stemberk J, Rowberry MD. The use of speleothem damage and in situ fault displacement monitoring to characterise active tectonic structures: an example from Západní Cave, Czech Republic. Acta Carsologica. 2014;43(1):129-138.

40. Méjean P, Garduño-Monroy VH, Pinti DL, et al. U-Th dating of broken speleothems from Cacahuamilpa cave, Mexico: Are they recording past seismic events? Journal of South American Earth Sciences. 2015;57:23-31.

41. Folk RL. Clasificación de las rocas de carbonatos de acuerdo a las proporciones relativas de los tres constituyentes básicos: granos (aloquimicos), matriz micritica y cemento, esparítico (ortoquímicos). Boletín de la Asociación Americana de Geólogos del Petróleo. 1962;43.

42. Folk RL. Petrology of sedimentary rocks. Hemphills, Austin Tex. $1974 ; 170$

43. Dunham RJ. Clasificación de las rocas de carbonatos de acuerdo a la textura de deposición. In: Jamón WE, Editors. AAPG. 1962.

44. Dowling RK, Newsome D. Geotourism's Issues and Challenges, Geotourism, Chapter Thirteen. Elsevier, Oxford. 2006;242-254.

45. Allemand J. Espeleoturismo: La importancia de capacitar guías turísticos especializados. Sociedad Argentina De Espeleología Boletín 3 BsAs, Argentina. 2005;2-3.

46. Bojórquez-Vargas A, Bello-Baltazar E, Márquez-Rosano C, et al Forestería comunitaria y desarrollo de instituciones locales: el caso de la Comunidad Agraria Teopisca. Economía, Sociedad y Territorio. 2009;IX(30):349-395.

47. Amado GE, Morales L. Relación de los Procesos de denudación y el sistema de fracturas en la génesis de las cavernas del Parque Nacional Natural Cueva de Los Guácharos. Trianea. 1991;4:597-621.

48. Carrillo A, Pavajeau H, Rojas E. Estudio Geoespeleológico de la Caverna Sabana de León, Municipio de Manaure, Serranía de Perijá, Cesar. Revista Agunkuya. 2017;1(1):7-15.

49. Forero A. Estratigrafía del Pre cretácico en el flanco occidental de la Serranía de Perijá. Revista Geología Colombiana. 1972;7:7-78. 